\title{
Crisis Measures of Institutional Reform for the European Court of Human Rights
}

\section{Alastair Mowbray, Professor of Public Law, University of Nottingham}

(C) A.R. Mowbray

This is a pre-copy-editing, author-produced PDF of an article accepted for publication in Human Rights Human Rights Law Review. VOL 9(4), 647-656 following peer review. The definitive publisherauthenticated version is available online at: http://hrlr.oxfordjournals.org/cgi/reprint/ngp023? $i j k e y=R T X J v X p L 2 D I R b c w \& k e y t y p e=r e f]$.

The ever increasing difficulties that the European Court of Human Rights (hereafter the Court) has faced in handling the remorseless increase in applications being lodged with it has been a topic regularly analysed in this journal. ${ }^{1}$ Indeed, the first issue contained an examination of the emerging backlog of cases and President Wildhaber's initial thoughts on institutional reform of the full-time Court. $^{2}$ In 2007 we noted the Russian Duma's rejection of Protocol 14, thereby preventing Russian ratification of the Protocol. ${ }^{3}$ Despite repeated public requests from both the political and judicial organs of the Council of Europe the Russian authorities have still not ratified this Protocol, with the consequence that it has not been able to be implemented even though all the other 46 State parties had ratified the Protocol by the autumn of 2006. In April 2008 the Chair of the Legal Affairs and Human Rights Committee of the Council of Europe's Parliamentary Assembly wrote to the Head of the Russian delegation to the Assembly referring to the possibility

\footnotetext{
${ }^{1}$ See for example L. Caflisch, The Reform of the European Court of Human Rights: Protocol No. 14 and Beyond", 6(2) Human Rights Law Review 403.

${ }^{2}$ A. Mowbray, "The Workload of the European Court of Human Rights", 1(1) Human Rights Law Review 128.
}

\footnotetext{
3 A. Mowbray, "Faltering Steps on the Path to Reform of the Strasbourg Enforcement System" 7(3) Human Rights Law Review 609.
} 
of parties to a treaty voluntarily applying its provisions on a provisional basis prior to the formal entry into force of the treaty. ${ }^{4}$ She based her letter on Article 25 of the Vienna Convention on the Law of Treaties $(1969)^{5}$ which provides that:

1. A treaty or part of a treaty is applied provisionally pending its entry into force if:

(a) the treaty itself so provides; or

(b) the negotiating States have in some other manner so agreed.

2. Unless the treaty otherwise provides or the negotiating States have otherwise agreed, the provisional application of a treaty or part of a treaty with respect to a State shall be terminated if that State notifies the other States between which the treaty is being applied provisionally of its intention not to become a party to the treaty.

Subsequently, in October 2009, President Costa of the Court had a meeting with the Committee of Ministers' Liaison Committee with the European Court of Human Rights during which he mooted the "urgent implementation" of some of the procedural reforms contained in Protocol 14 because of the "extremely serious situation facing the Court". ${ }^{6}$ He expressed the view that the introduction of the single-judge formation to determine the (in)admissibility of weak applications and the empowering of Committees (composed of three Judges) to determine the merits of repetitive cases could increase the Court's efficiency by 20-25 percent. These reforms could not solve the workload crisis, but would be "an extremely useful contribution".

The Committee of Ministers, working through its Deputies, swiftly acted upon President Costa's suggestion and during the following month the Deputies asked the

\footnotetext{
4 "Draft Protocol 14 bis to the Convention for the Protection of Human Rights and Fundamental Freedoms: Report of the Committee on Legal Affairs and Human Rights", Rapporteur K. De Vries at B 11, Parl Assembly Doc. 11879 (28 April 2009) : all Council of Europe documents cited are available from www.coe.int .
}

${ }^{5}$ UN Treaty Series vol 1155 p.331.

${ }^{6}$ Explanatory Report to Protocol 14 bis to the ECHR, CM(2009)58 addendum final. 
Steering Committee on Human Rights $(\mathrm{CDDH})^{7}$ and the Committee of Legal Advisers on Public International Law (CAHDI) ${ }^{8}$ for their opinions on the desirability and methods of implementing President Costa's request. The latter body submitted its opinion on 31 March 2009. ${ }^{9}$ CAHDI began by noting that the "fastest, simplest" way of introducing these procedural reforms was through all Member States ratifying Protocol 14. It also observed that during the drafting of Protocol 14 the secretariat had suggested incorporating an article enabling the provisional application of the Protocol, but that States had not then considered it apposite. Now, the Court's Registry did not foresee any technical problems in applying these procedural reforms contained in Protocol 14. CAHDI dismissed the idea that such institutional measures could be introduced via a dynamic interpretation of the European Convention on Human Rights (hereafter ECHR) or through changes to the Rules of the Court. Also, CAHDI rejected the suggestion that individual Member States might issue unilateral declarations consenting to the application of these procedural reforms to the determination of applications against them, without an agreement between all the Parties to the ECHR. In the view of CAHDI, States could not waive the application of procedural measures designed to benefit applicants (presumably, such as the role of Committees of three Judges determining the inadmissibility of individual application under Article 28 of the ECHR).

CAHDI advised that there were two options "fully compatible with the governing principles of public international law" 10 to enable the introduction of the specified

\footnotetext{
${ }^{7}$ Composed of one representative per Member State with an expertise in human rights: Terms of reference of the Steering Committee for Human Rights, Committee of Ministers meeting 11-12 February 2009, Appendix 5.

${ }^{8}$ Composed of the legal adviser of each Minister of Foreign Affairs of Member States: see www.coe.int/cahdi .

${ }^{9} \mathrm{CM}(2009) 56$ addendum.

${ }^{10}$ Ibid. at Conclusions para. 2.
} 
procedural reforms before Protocol 14 entered into force. First, a new Protocol authorising the temporary use of the designated procedural measures could be agreed by the Member States, following the established practice of the Committee of Ministers. CADHI recommended that such a Protocol should contain clauses allowing for its provisional application (when a defined number of States had expressed their agreement) and a "sunset" article terminating the Protocol once Protocol 14 was fully ratified. Second, a gathering of the State Parties to Protocol14 reaching an agreement, by consensus, to allow the provisional application of the specified measures in cases against States that expressed their consent. CAHDI believed that as Protocol 14 does not contain an express clause authorising provision application then, in accordance with Article $25(1)(b)$ of the Vienna Convention, the "negotiating States" must agree such a development. Monaco, Montenegro and the Republic of Serbia were not negotiating States in respect of Protocol 14, as they were not members of the Council of Europe/did not exist in their current form, at that time. Subsequently, they ratified the Protocol. However, CADHI foresaw no difficulties in enabling them to participate in the agreement process. CAHDI noted that Article 25(1)(b) does not elaborate a procedure for negotiating States to reach an agreement on provisional application. "Accordingly, a decision by consensus and absence of disagreement by any negotiating state would be a legally sound basis for an agreement on provisional application." ${ }^{11}$ CAHDI advised that an agreement on the provisional application of Protocol 14 should contain a clause specifying whether it applies to all applications pending before the Court against the relevant State. The entering into force of Protocol 14 should result in the termination of the agreement on provisional application. Either of the above solutions would involve the Court in using two different procedures when determining applications against

\footnotetext{
${ }^{11}$ Ibid. at para. 34.
} 
Member States according to whether they had consented to the reform measures or were still governed by the Protocol 11 process.

$\mathrm{CDDH}$ produced its Final Opinion in March 2009. ${ }^{12}$ It observed that the Court's backlog was continuing to grow and had reached 102,720 pending cases in February 2009. ${ }^{13}$ Therefore, it supported the swift introduction of the two procedural reforms by the Court. Initially $\mathrm{CDDH}$ had considered the possibility of also recommending the provisional application of the new admissibility criteria contained in Protocol $14^{14}$, but it concluded that it would be best to focus on the two procedural reforms and not seek to introduce the provisional application of changes to substantive rights enshrined in the ECHR. Like CAHDI the CDDH also considered the prompt ratification of Protocol 14 by Russia (not mentioned by name) would be ideal solution. "...[T]his would result in the entire Protocol coming into force between three and four months later, thus greatly reducing any delay; would present no complications under public international law; would avoid any difficulties under the national constitutional law of other State parties that have already ratified the Protocol; and would avoid any risks of the Court having to operate two different sets of procedures for two sets of states." ${ }^{15}$ Nevertheless, regarding the modalities of securing the provisional application of the specific procedural reforms, $\mathrm{CDDH}$ focussed on the two methods examined by CAHDI.

\footnotetext{
${ }^{12}$ However, it was not declassified and published until May 2009: CM(2009)51 Addendum final.

${ }^{13}$ Ibid. para. 5.
}

${ }^{14}$ See A. Mowbray, Cases \& Materials on the ECHR $2^{\text {nd }}$ ed (Oxford: Oxford University Press 2007) at 53 and D. J. Harris, M. O'Boyle, E.P. Bates \& C.M. Buckley, Law of the ECHR $2^{\text {nd }}$ ed (Oxford: Oxford University Press 2009) at 865-866.

\footnotetext{
${ }^{15}$ Ibid. para.12.
} 
$\mathrm{CDDH}$ considered that all the States party to the ECHR should reach an agreement to permit the provisional application of the specified procedural reforms by individual States which wished to do so. However, $\mathrm{CDDH}$ believed that domestic constitutional requirements would oblige "most" States to seek parliamentary approval before being able to consent to provisional application. As to the option of States agreeing a new Protocol $14 \mathrm{bis}^{16} \mathrm{CDDH}$ disagreed with CAHDI's view that the new Protocol should contain a clause allowing for its provisional application. In the former's opinion if Protocol 14bis had a low threshold number of ratifications for entry into force then provisional application would not be necessary. As to the appropriate size of the "critical mass" of State ratifications needed CDDH considered that one, as suggested by the Court's Registrar, would have the benefit of enabling the speediest introduction of the reforms; two would be the minimum number relevant for an international agreement and three the minimum pertinent for a multilateral agreement. Finally, $\mathrm{CDDH}$ observed that the options of States agreeing to allow the provisional application of Protocol 14 or agreeing Protocol 14bis could both be pursued.

After receiving the opinions of CAHDI and CDDH the Committee of Ministers' Rapporteur Group on Human Rights (GR-H) worked on a draft of Protocol 14bis. On 21 April 2009 the Chair of the Committee of Ministers' Deputies wrote to the President of the Parliamentary Assembly inviting the latter body to give its opinion on the draft Protocol, under the urgent procedure of the Assembly at its forthcoming session. The Assembly's Committee on Legal Affairs and Human Rights produced a Report ${ }^{17}$ which began by acknowledging that:

\footnotetext{
${ }^{16}$ The Concise Oxford English Dictionary $11^{\text {th }}$ ed (Oxford: Oxford University Press 2008) defines it as meaning "to be repeated" derived from Latin literally "twice".

${ }^{17}$ Supra n. 4.
} 
...there is widespread agreement, both within the Parliamentary Assembly and the Committee of Ministers that if a temporary, interim solution is not quickly found to help the Court to substantially increase its case-processing capacity, the Court will be in danger of collapsing under the weight of its caseload.

If follows that the Court must urgently find a way in which to deal with, in particular, three matters: judges must not spend too much time on obviously inadmissible cases (approximately $95 \%$ of all applications), they must deal expeditiously with repetitive cases that concern already clearly established systemic defects within states (this represents approximately $70 \%$ of cases dealt with on the merits) and by doing so, concentrate their work on the most important cases and deal with them as quickly as possible. ${ }^{18}$

The Report, unlike the government dominated Opinions of CAHDI and CDDH, went on to expressly criticise the Russian Parliament.

The Russian State Duma's attitude on this subject is difficult to comprehend, especially as it's position is totally out of line with that of all the other 46 State Parties to the Convention, including their legislative organs, and even its own Executive. ...If it were not for the Russian State Duma's intransigence, we would not have run into the problems we are facing today! So I can only deplore the State Duma's refusal to provide its assent, since December 2006, to the ratification of Protocol No 14 by Russia. By so doing, the State Duma has, in effect, considerably aggravated the situation in which the Court has found itself, and has also deprived persons within the jurisdiction of the Russian Federation from benefitting from a streamlined case-processing procedure before the Court. ${ }^{19}$

The draft of Protocol 14 bis was endorsed as "a good interim solution" 20 and the Report only suggested a few technical linguistic changes to the text ${ }^{21}$.

The Parliamentary Assembly debated draft Protocol 14bis on 30 April 2009. $\mathrm{Mr}$ Kox (from the Netherlands) expressed the view that Russia was unlikely to ratify Protocol 14 "in the near future". Nevertheless, he considered that even if Russia was to do so the ECHR system still faced the problem that until national judicial systems

${ }^{18}$ Ibid. at paras. B. II. 4 and 6.

${ }^{19}$ Ibid. at para. 10.

${ }^{20}$ Ibid. at para 17.

${ }^{21}$ Such as the replacement of "Parties" with "the High Contracting Parties". 
provided effective protection for Convention rights victims would continue to seek justice at Strasbourg. Mr Hunault (from France) noted that the debate was occurring "because of the blocking tactics of one of the delegations" and that Russian members of the Parliamentary Assembly were not present to participate in the deliberations. The Parliamentary Assembly concluded its debate by approving Opinion $271^{22}$ with 39 votes in favour and none against or abstaining. The Opinion "strongly deplored" the Russian Duma's stance on Protocol 14 and supported the introduction of Protocol 14 bis as a temporary resolution of the problem.

After considering the Parliamentary Assembly's Opinion the Ministers' Deputies agreed, on 6 May, the text of draft Protocol 14 bis. This text incorporated the linguistic changes recommended by the Assembly. The draft was then transmitted to the Committee of Ministers. At the $119^{\text {th }}$ Session of the Committee of Ministers, held in Madrid on 12 May, the High Contracting Parties to the ECHR organised a separate Conference. During that gathering the Member States adopted Protocol 14 bis. They also agreed by consensus ${ }^{23}$ that parties to Protocol14 could consent to the provisional application of the single-judge formation and extended powers of Committees to cases brought against them. So both strategies endorsed by CAHDI were given effect by the Member States. However, the Minsters formally;

noted that in spite of the efforts undertaken by all member states as collective guarantors of the Convention, the conditions for the entry into force of Protocol No. 14 have still not been met. The Ministers recalled their position on the issue expressed at their $118^{\text {th }}$ Session in May 2008, stressing in particular that the entry into force of Protocol No. 14 should remain the first priority of the States Parties to the ECHR. ${ }^{24}$ (my emphasis)

\footnotetext{
${ }^{22}$ Opinion No 271 (2009), 30 April 2009.
}

\footnotetext{
${ }^{23}$ Subject to the absence of opposition by 31 May 2009 of any High Contracting Party not present at the Conference: Statement by the Committee of Ministers on the Conference of the High Contracting Parties to the ECHR (Madrid, 12 May 2009), CM(2009)60 final. No formal objection was subsequently made.
} 
The Georgian Delegation issued a position paper which, inter alia, took issue with the above comments. "Perhaps, too straightforward approach may not be productive, but I fear that excessive moderation chosen for the Statement will not solve the issue either." ${ }^{25}$ We may speculate that given the military conflict between Georgia and Russia in the summer of 2008 and the subsequent initiation of large-scale litigation before the Court over the matter ${ }^{26}$ the Georgian government felt less tolerant of the Russian response to Protocol 14 than other Member States. Indeed, we have seen above how the Parliamentary Assembly expressly criticised the Duma. Presumably, the Ministers adopted a more diplomatic stance in order to both facilitate the Russian government not objecting to the Conference's dual provisional measures strategy whilst also seeking to avoid inflaming the Duma's anti-ECHR attitude.

Turning to the substance of Protocol 14 bis, the roles and functions of singlejudge formations and the extended powers of Committee have been analysed in a previous issue of the Review ${ }^{27}$ so we shall not repeat ourselves. Interestingly, the final text of 14 bis discloses that the Member States rejected the view of $\mathrm{CDDH}$ that it was not necessary to incorporate a clause enabling States to authorise the provisional application of the Protocol to them. Article 7 provides that:

[p]ending the entry into force of this Protocol according to the conditions set under Article 6, a High Contracting Party to the Convention having signed or ratified the

\footnotetext{
${ }^{25}$ Position paper of the Georgian Delegation for the $119^{\text {th }}$ Session of the Committee of Ministers: DD(2009)273.
}

\footnotetext{
${ }^{26}$ In October the Court's Registrar issued a Press Release disclosing that 2,792 applications from South Ossetians had been lodged against Georgia in respect of its military activities during August 2008 and Georgia had initiated an inter-state complaint against the Russian Federation concerning the conflict: Press Release 10 October 2008, available from www.echr.coe.int/HUDOC.
}

\footnotetext{
${ }^{27}$ A. Mowbray, "Protocol 14 and Recent Strasbourg Cases" 4(2) Human Rights Law Review *** (2004).
} 
Protocol may, at any moment, declare that the provisions of this Protocol shall apply to it on a provisional basis. Such a declaration shall take effect on the first day of the month following the date of its receipt by the Secretary General of the Council of Europe. ${ }^{28}$

The Explanatory Report justified the inclusion of this "opt in" so as to "facilitate the earliest possible application of the protocol with respect to the largest possible number of High Contracting Parties, since domestic procedures prior to expression of consent to be bound may be lengthy." ${ }^{29}$ Under Article 6 of Protocol 14 bis three High Contracting Parties have to ratify (or sign without reservation as to ratification) the Protocol for it to enter into force. This is the lowest number of ratifications appropriate for a multilateral treaty according to the CDDH Opinion we examined previously. The Explanatory Report described this threshold as being "'very low... in order to allow the protocol to enter into force as quickly as possible." 30 Under Article 8 of the Protocol when either the Protocol enters into force or it becomes provisionally applicable to a High Contracting Party then all applications pending before the Court against the relevant State(s) will be determined in accordance with the new procedures. Finally, Article 9 provides that when Protocol 14 enters into force Protocol 14 bis will cease to be in force or be applied on a provisional basis (if the minimum number of ratifications had not been achieved). The Explanatory Report notes that such a development will make no difference to those States whose cases have been determined in accordance with Protocol 14 bis.

Protocol 14 bis was formally opened for signature on 27 May 2009 and on the same day President Costa, who we have already learnt played a leading role in

\footnotetext{
${ }^{28}$ Protocol No. 14 bis to the European Convention on Human Rights: CM(2009)58 final.

${ }^{29}$ Supra n.6 at para. 23.
}

${ }^{30}$ Ibid. at para. 22. 
stimulating the creation of the Protocol, publically "thanked the Member States that had worked hard to make this Protocol possible, thereby showing their attachment to the protection mechanism enshrined in the ECHR. ${ }^{\prime 31}$ Both Denmark and Norway ratified the Protocol on that day too. Subsequently, on 17 June 2009, Ireland also ratified the Protocol. Consequently, Protocol 14 bis will enter into force on 1 October 2009. Furthermore, Norway made a declaration, under Article 7 of Protocol 14 bis, on 25 May, so cases pending or brought against that State from 1 June 2009 are being determine by the new processes. Denmark likewise made a similar declaration on 3 June so that cases against it have been considered under the new arrangements since 1 July 2009.

Regarding the other provisional measures option agreed at the Madrid conference, Switzerland, on that day, made a declaration that it would accept the provisional application of the identical reforms under Protocol 14 to be applied to cases pending or brought against it from 1 June 2009. Germany made a similar declaration on 29 May, which also came into effect on 1 June. The Netherlands and Luxembourg issued declarations in June, which became effective on 1 July. ${ }^{32}$ So, two years after the Court hoped that Protocol 14 would be fully in force, the single-judge formations and extended powers of Committees have begun to become operational in respect of an expanding minority of States. It is regrettable that so much diplomatic and legal effort has had to be expended to partially circumvent the Russian Duma's blocking of Protocol 14. But, on a positive note the willingness of the Member States, without the Russian Government lodging a formal objection, to utilise innovative techniques (e.g. there has previously

\footnotetext{
31 "President Costa welcomes the opening for signature of Protocol 14 bis", Press Released issued by the Registrar (27/5/2009).

${ }^{32}$ Details of the formalities governing the making of these declarations and the dates of individual declarations are available from the Council of Europe Treaty website, Protocol 14, Agreement on the provisional application of certain provisions of Protocol 14 pending its entry into force: http://conventions.coe.int
} 
never been a bis Protocol created under the ECHR system) in order to enable crucial institutional reforms to be implemented by the Court must be welcomed. The two provisional measures strategies agreed at the Madrid conference demonstrate that the Member States do genuinely support the need to empower the Court to re-organise its methods of processing the torrent of complaints flowing to Strasbourg. Furthermore, the rapid action of several States in ratifying Protocol 14 bis or making declarations of provisional application under Protocol 14 provides additional evidence of real commitment to the ECHR system. It is to be hoped that the remaining governments will be inspired to authorise the application of the single-judge/extended powers Committees processes to complaints against their States via whichever provisional measures strategy involves the least delay to comply with their constitutional obligations. Then the next major challenge for States regarding their attitude towards future radical reforms of the ECHR system is President Costa's call for a conference to be held in 2010:

The idea is for the States, guarantors of human rights, to give human rights protection a second wind. That would help to express support for the Court and to pump new life into this fifty-year-old by offering it a cure of youthfulness. ${ }^{33}$

We will no doubt be analysing how this proposal develops in future issues of the Review.

\footnotetext{
${ }^{33}$ Speech given at the opening of the judicial year, 30 January 2009 at p. 7.
} 